\title{
Is Immunohistochemistry Enough to Diagnose Xp11.2 Renal Cell Carcinoma?
}

\section{Paulo Victor Zattar Ribeiro* and Leonora Zonula Pope, MD}

Department of Medicine, University of the Region of Joinville, Brazil

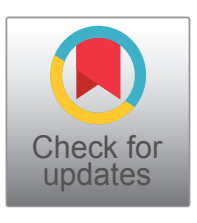

*Corresponding author: Paulo Victor Zattar Ribeiro, Student, Department of Medicine, University of the Region of Joinville, Rua Ministro Calógeras, 439, Bucarein, Joinville, Santa Catarina, 892020-207, Brazil, Tel: 55+47-9-9625-1142

\begin{abstract}
The correct diagnosis methods of Renal Cell Carcinoma (RCC) with $\mathrm{Xp} 11.2$ translocations are controversial in the current literature. Due to the possible failures of immunohistochemistry alone. So we present a possible scientific based answer with the articles yet available.
\end{abstract}

\section{Keywords}

Renal cell carcinoma, XP11.2 translocation

\section{Introduction}

Renal cell carcinoma (RCC) with Xp11.2 translocations was delineated as a distinct entity in 2004 by the World Health Organization. It was primarily associated with TFE3 gene fusion and TFE3 protein overexpression in immunohistochemistry. It's known that its morphology and clinical manifestations normally overlap with those of conventional RCCs [1]. One curious fact is that children are more affected by this subtype than adults, accounts for $20-40 \%$ of pediatric RCC and $1-1.6 \%$ of RCC in adults, its prognosis is also better in children [2]. The exact incidence of TFE3 translocation renal cell carcinoma among adults remains debatable but estimates range from 1 to $4 \%$ of all renal cell carcinoma, with approximately 2500 new cases diagnosed every year [3-5]. In adults, TFE3 translocation renal cell carcinoma is an aggressive tumor with overall survival similar to that of clear cell renal cell carcinoma $[4,6,7]$.

Xp11.2 RCC is a rare subtype of RCC which results from gene fusions between the transcription factor E3 (TFE3) gene and at least 5 fusion partners including ASPL-TFE3, PRCC-TFE3, PSF-TFE3, CLTC-TFE3, and No-
no-TFE3, whose chromosomal rearrangement is $t(X ; 17)$ (p11.2;q25), $\quad t(X ; 1)(p 11.2 ; q 21), \quad t(X ; 1)(p 11.2 ; p 34)$, $t(X ; 17)(p 11.2 ; q 23)$ and $\operatorname{inv}(X)(p 11.2 ; q 12)$, respectively $[8,9]$.

Due to the translocations lead to overexpression of TFE3 protein, detection of TFE3 protein by IHC assay is currently the most commonly used diagnostic technique in clinical practice [10]. So it's known that Xp11 translocation renal cell carcinoma is cytogenetically characterized by chromosomal translocations involving breakpoints in the TFE3 gene, which maps to the Xp11.2 locus. Histologically, a wide spectrum of morphology has been described in these tumors, emphasizing the need to consider these carcinomas in the differential diagnosis of unusual renal cell carcinomas occurring in either children or adults [3]. Also, it's important to say that the gross features of Xp11.2 translocation RCC are similar to those of conventional clear cell RCC. Macroscopically, the cut surfaces of the tumors are greyish-yellow in color and exhibit hemorrhaging and necrosis. Morphologically, the tumors comprise a combination of nested and papillary structures with clear-to-granular eosinophilic cytoplasm [11]. In contrast, the different subtypes of Xp11.2 translocation RCC are histopathologically distinct. Typically, cells of the alveolar soft part sarcoma chromosome region (ASPSCR)-TFE3 subtype are characterized by a higher amount of clear-to-eosinophilic cytoplasm relative to the other subtypes, and exhibit discontinuous cell boundaries, vesicular nuclei, and obvious nucleoli. In contrast, the typical features of PRCC-TFE3 Xp11.2 translocation RCC include a diminished cytoplasm, fewer psammoma bodies and hyaline globules, and a more nested structure [12]. 
Strong nuclear TFE3 immunohistochemical expression is a reasonably sensitive and specific marker for Xp11 translocation renal cell carcinoma [13]. With that being said Gaillot-Durand, et al. showed that nuclei stained with an intensity of ++ to +++ in IHC assay was necessary to suspect the diagnosis of Xp11.2 RCC [14]. However, recent studies have found that the positive predictive value of positive TFE3 staining for Xp11.2 RCC is very low as well as highly false positive results [15]. With that in mind, the diagnosis of Xp11.2 RCC should be not only made by IHC assay but also by such strict criteria as Fluorescence in situ hybridization (FISH) assay and other molecular biology [16].

In conclusion, we strongly believe that immunohistochemistry alone is not enough to diagnose Xp11.2 RCC and that it should be confirmed by another cytogenetic technique.

\section{Sources of Support}

We declare no financial support and no material support.

\section{Conflict of Interest}

All authors declare that there are no conflicts of interest.

\section{Authors Contribution}

And that all authors had an equally contribution.

\section{References}

1. Bruder E, Passera O, Harms D, Leuschner I, Ladanyi M, et al. (2004) Morphologic and molecular characterization of renal cell carcinoma in children and young adults. Am J Surg Pathol 28: 1117-1132.

2. Kmetec A, Jeruc J (2014) Xp 11.2 translocation renal carcinoma in young adults; recently classified distinct subtype. Radiol Oncol 48: 197-202.

3. Argani P (2015) MiT family translocation renal cell carcinoma. Semin Diagn Pathol 32: 103-113.

4. Sukov WR, Hodge JC, Lohse CM, Leibovich BC, Thompson $\mathrm{RH}$, et al. (2012) TFE3 rearrangements in adult renal cell carcinoma: Clinical and pathologic features with outcome in a large series of consecutively treated patients. Am J Surg Pathol 36: 663-670.

5. Zhong M, DeAngelo P, Osborne L, Paniz-Mondolfi AE, Geller $M$, et al. (2012) Translocation renal cell carcinomas in adults: A single-institution experience. Am J Surg Pathol 36: 654-662.
6. Srigley JR, Delahunt B, Eble JN, Egevad L, Epstein JI, et al. (2013) The International Society of Urological Pathology (ISUP) Vancouver Classification of Renal Neoplasia. Am J Surg Pathol 37: 1469-1489.

7. Hora M, Urge T, Trávníček I, Ferda J, Chudáček Z, et al. (2014) MiT translocation renal cell carcinomas: Two subgroups of tumours with translocations involving $6 \mathrm{p} 21$ [ $\mathrm{t}(6$; 11)] and $X p 11.2$ [t ( $X ; 1$ or $X$ or 17)]. Springerplus 3: 245.

8. Wang W, Ding J, Li Y, Wang C, Zhou L, et al. (2014) Magnetic resonance imaging and computed tomography characteristics of renal cell carcinoma associated with Xp11.2 translocation/TFE3 gene fusion. PLoS One 9: e99990.

9. Liu K, Xie P, Peng W, Zhou Z (2014) Renal carcinomas associated with $\mathrm{Xp11.2}$ translocations/TFE3 gene fusions: Findings on MRI and computed tomography imaging. $J$ Magn Reson Imaging 40: 440-447.

10. Komai Y, Fujiwara M, Fujii Y, Mukai H, Yonese J, et al. (2009) Adult Xp11 translocation renal cell carcinoma diagnosed by cytogenetics and immunohistochemistry. Clin Cancer Res 15: 1170-1176.

11. Xu Z-Y, Wang J-P, Zhang Y, Wu S-W, Ma L, et al. (2019) Xp11.2 translocation/TFE3 gene fusion renal cell carcinoma with a micropapillary pattern: Cases report and literature review. Am J Transl Res 11: 327-339.

12. Argani $P$, Antonescu CR, Couturier J, Fournet JC, Sciot R, et al. (2002) PRCC-TFE3 renal carcinomas: Morphologic, immunohistochemical, ultrastructural, and molecular analysis of an entity associated with the $t(X ; 1)(p 11.2 ; q 21)$. Am J Surg Pathol 26: 1553-1566.

13. Argani $P$, Lal $P$, Hutchinson $B$, Lui MY, Reuter VE, et al. (2003) Aberrant nuclear immunoreactivity for TFE3 in neoplasms with TFE3 gene fusions: A sensitive and specific immunohistochemical assay. Am J Surg Pathol 27: 750761.

14. Gaillot-Durand L, Chevallier M, Colombel M, Couturier J, Pierron G, et al. (2013) Diagnosis of Xp11 translocation renal cell carcinomas in adult patients under 50 years: Interest and pitfalls of automated immunohistochemical detection of TFE3 protein. Pathol Res Pract 209: 83-89.

15. Skala SL, Xiao H, Udager AM, Dhanasekaran SM, Shukla $S$, et al. (2018) Detection of 6 TFEB-amplified renal cell carcinomas and 25 renal cell carcinomas with MITF translocations: Systematic morphologic analysis of 85 cases evaluated by clinical TFE3 and TFEB FISH assays. Mod Pathol 31: 179-197.

16. Klatte T, Streubel B, Wrba F, Remzi M, Krammer B, et al. (2012) Renal cell carcinoma associated with transcription factor E3 expression and Xp11.2 translocation: Incidence, characteristics, and prognosis. Am J Clin Pathol 137: 761768. 